\title{
The gut microbiota and inflammatory noncommunicable diseases: Associations and potentials for gut microbiota therapies
}

\author{
Christina E. West, Harald Renz, Maria Jenmalm, Anita L. Kozyrskyj, Katrina J. Allen, Peter \\ Vuillermin, Susan L. Prescott, Charles MacKay, Seppo Salminen, Gary Wong, John Sinn, \\ Jakob Stokholm, Hans Bisgaard, Ruby Pawankar, Paul Noakes, Doerthe Kesper and Meri \\ Tulic
}

\section{Linköping University Post Print}

\section{Tweet}

N.B.: When citing this work, cite the original article.

Original Publication:

Christina E. West, Harald Renz, Maria Jenmalm, Anita L. Kozyrskyj, Katrina J. Allen, Peter Vuillermin, Susan L. Prescott, Charles MacKay, Seppo Salminen, Gary Wong, John Sinn, Jakob Stokholm, Hans Bisgaard, Ruby Pawankar, Paul Noakes, Doerthe Kesper and Meri Tulic, The gut microbiota and inflammatory noncommunicable diseases: Associations and potentials for gut microbiota therapies, 2015, Journal of Allergy and Clinical Immunology, (135), 1. http://dx.doi.org/10.1016/j.jaci.2014.11.012

Copyright: Elsevier http://www.elsevier.com/

Postprint available at: Linköping University Electronic Press http://urn.kb.se/resolve?urn=urn:nbn:se:liu:diva-114013 
The relationship between gut microbiota and inflammatory non-communicable diseases and the potential role for gut microbiota as therapy

Christina E West MD, PhD ${ }^{\mathrm{a}, \mathrm{b}}$, Harald Renz MD ${ }^{\mathrm{a}, \mathrm{c}}$, Maria C Jenmalm PhD ${ }^{\mathrm{a}, \mathrm{d}}$, Anita L Kozyrskyj PhD ${ }^{\mathrm{a}, \mathrm{e}}$, Katrina J Allen MD, PhD ${ }^{\mathrm{a}, \mathrm{f}}$, Peter Vuillermin MD, PhD ${ }^{\mathrm{a}, \mathrm{g}}$, Susan L Prescott $\mathrm{MD}, \mathrm{PhD}^{\mathrm{a}, \mathrm{h}}$

On behalf of the in-FLAME Microbiome interest group:

Charles MacKay ${ }^{\mathrm{a}, \mathrm{i}}$, Seppo Salminen ${ }^{\mathrm{a}, \mathrm{j}}$, Gary Wonga ${ }^{\mathrm{a}, \mathrm{k}}$, John Sinn ${ }^{\mathrm{a}, \mathrm{l}}$, Jakob Stokholm ${ }^{\mathrm{a}, \mathrm{m}}$, Hans Bisgaard $^{\mathrm{a}, \mathrm{m}}$, Ruby Pawankar ${ }^{\mathrm{a}, \mathrm{n}}$, Paul Noakes ${ }^{\mathrm{a}, \mathrm{h}}$, Dörthe Kesper ${ }^{\mathrm{a}, \mathrm{c}}$, Meri Tulic ${ }^{\mathrm{a}, \mathrm{o}}$

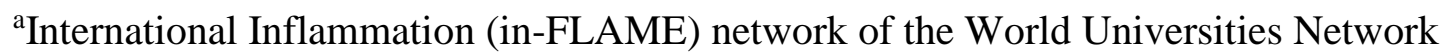

${ }^{b}$ Department of Clinical Sciences, Pediatrics, Umeå University, Umeå, Sweden

${ }^{\mathrm{c}}$ Department of Clinical Chemistry and Molecular Diagnostics, University of Marburg, Marburg, Germany

${ }^{\mathrm{d} D e p a r t m e n t ~ o f ~ C l i n i c a l ~ a n d ~ E x p e r i m e n t a l ~ M e d i c i n e, ~ L i n k o ̈ p i n g ~ U n i v e r s i t y, ~ L i n k o ̈ p i n g ~}$ Sweden

${ }^{\mathrm{e}}$ Department of Pediatrics, University of Alberta, Alberta, Canada

${ }^{\mathrm{f}}$ Murdoch Childrens Research Institute and Department of Pediatrics, University of Melbourne, Melbourne, Australia

${ }^{g}$ Child Health research Unit, Barwon Health, Geelong, Australia

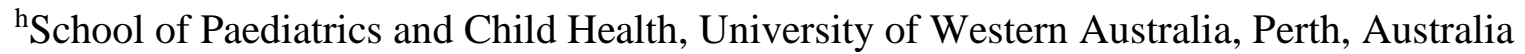
${ }^{\mathrm{i}}$ Faculty of Medicine, Monash University, Clayton, Australia

${ }^{j}$ University of Turku, Turku, Finland

${ }^{\mathrm{k}}$ Department of Paediatrics and School of Public Health, The Chinese University of Hong Kong,Hong Kong, China 
${ }^{1}$ Department of Neonatology, University of Sydney, Sydney, Australia

${ }^{\mathrm{m}}$ Copenhagen Prospective studies on Asthma in Childhood, Health Sciences, University of Copenhagen, Copenhagen, Denmark

${ }^{\mathrm{n}}$ Division of Allergy, Department of Pediatrics, Nippon Medical School, Tokyo, Japan

${ }^{\circ}$ Tolerance Immunitaire, Université de Nice Sophia-Antipolis, Nice, France

Correspondance to: A/Prof Christina West

Department of Clinical Sciences, Pediatrics

SE 90185 Umeå University, Umeå, Sweden

Email:christina.west@umu.se

Keywords: fecal microbiota transplantation; gut microbiome; inflammation; noncommunicable diseases; prebiotics; probiotics; short-chain fatty acids

List of abbreviations: CS-caesarean section; CRP-C-reactive protein; CVD-cardiovascular disease; DGGE -denaturing gradient gel electrophoresis; FISH- fluorescence in situ hybridization; FMT-fecal microbiota transplantation; HPA-hypothalamic-pituitary-adrenal; IBD- inflammatory bowel disease; NCD-non-communicable diseases; SCFA- short-chain fatty acid; VD-vaginally delivered; q-PCR- quantitative PCR; T-RFLP- terminal restriction fragment length polymorphism; TLR- Toll-like receptor; 16S- 16S rRNA gene

Total word count: 4665 (excluding the abstract)

Number of figures: 2

\section{Number of tables: 3}




\section{ABSTRACT}

Rapid environmental transition and modern lifestyles are likely to be driving changes in the biodiversity of human gut microbiota. With clear effects on physiological, immunological and metabolic processes in human health, aberrations in the gut microbiome and intestinal homeostasis have the capacity for multisystem effects. Changes in microbial composition are implicated in the rising propensity for a broad range of inflammatory diseases such as allergic disease, asthma, inflammatory bowel disease, obesity and associated non-communicable diseases (NCDs). There are also suggestive implications for neurodevelopment and mental health. These diverse multisystem influences have sparked interest in strategies that may favorably modulate the gut microbiota to reduce the risk of many NCDs. For example, specific prebiotics promote favorable intestinal colonization and their fermented products have anti-inflammatory properties. Specific probiotics also have immunomodulatory and metabolic effects. However, when evaluated in clinical trials the effects are variable, preliminary or limited in magnitude. Fecal microbiota transplantation (FMT) is another emerging therapy that regulates inflammation in experimental models. In humans this has been successfully used in Clostridium difficile infection and inflammatory bowel disease (IBD), although controlled trials are lacking for IBD. Here, we discuss relationships between gut colonization and inflammatory NCDs, and gut microbiota modulation strategies for their treatment and prevention. 


\section{Introduction}

The health of our modern society is being threatened by a plethora of chronic inflammatory non-communicable diseases (NCDs) which share in common, an underlying low-grade inflammation. These include early onset NCDs such as allergy, asthma and some autoimmune diseases and later onset NCDs including cardiovascular disease (CVD), metabolic disease and neurodegenerative disorders - which also appear to share common environmental risk factors ${ }^{1}$ as well as common genetic risk variants ${ }^{2}$. While inflammation and the pathways to disease are multifactorial, the altered gut colonization patterns associated with declining microbial diversity is a central theme, and increasingly implicated in the physiological, immunological and metabolic dysregulation seen in many NCDs. The adult gut harbors as many as 100 trillion resident microbes called the microbiota and the corresponding genome (microbiome) has been estimated to contain 150 -fold more genes than the host genome ${ }^{3}$. These complex communities have a symbiotic relationship with the host, and are involved in many aspects of host physiology. Generally, the two main phyla in adults are Bacteroidetes comprising Gramnegative bacteria and Firmicutes comprising Gram-positive bacteria ${ }^{4}$. The cell wall of gramnegative bacteria contains lipopolysaccharides (LPS), which induce a strong host inflammatory response to protect from infection. Under normal conditions, finely tuned regulatory responses restrict excessive inflammation and maintain tissue equilibrium ${ }^{5-8}$. The pattern of microbial exposure in early life appears to be important for the development of robust host immune regulation, and disruption in either the microbiota or the host response can lead to chronic inflammation. In this context, reduced exposure to commensals, helminths and other infectious agents in affluent countries is a likely contributor, at least in part, to the rising propensity for chronic low-grade inflammation and impaired immuneregulation ${ }^{9-11}$. Our classical understanding of inflammation is of a normal physiological response to an infectious threat, or tissue injury. Inflammation leads to tissue repair, 
resolution and restoration of the 'homeostatic' balance in the tissues. But the chronic inflammatory states of asthma, allergy, obesity, diabetes, atherosclerosis and other NCDs do not appear to fit this model. There is usually no acute or immediate threat; and there is no resolution. Instead there appears to be a chronic tissue malfunction and a shift of the normal homeostasis or 'balance' to adapt to new physiological or metabolic conditions ${ }^{12}$. Disruption in the interrelationships between nutrition, and microbiome and host metabolism are likely to be key elements in the disruption of normal homeostasis. Dysbiosis - "an imbalance in microbiota structure and/or function that disrupts host-microorganism homeostasis" - is an emerging feature of many NCDs ${ }^{6,8}$. This concept is driving strategies to favorably impact gut microbiota. However, a significant limiting factor is that the "normal, healthy gut microbiota" is yet to be clearly defined, including the range and variant profiles, and developmental windows that are likely to fall within this spectrum. To overcome this, large-scale

investigations of the human microbiome e.g. the Human Microbiome Project ${ }^{13,14}$ and MetaHit ${ }^{3}$ are rapidly advancing our understanding by defining microbial compositions and their functions in large populations using coordinated strategies for project planning, analytic techniques and education programs ${ }^{15}$. Clearly, experimental models have also provided invaluable insights ${ }^{6,8}$, but our emphasis here is on the human dimension, with a focus on recent observational studies that have assessed intestinal colonization patterns and their associations to NCDs, and clinical trials that have explored gut microbiota modulation as a therapeutic strategy in both early and late onset NCDs.

\section{Methods for the investigation of the gut microbiota and microbiome}

Accelerating development of molecular biology methods to characterize the gut microbiome, has rapidly advanced knowledge in this field. Next-generation sequencing, computer technology, and advanced analytical strategies for the handling of ever-expanding biological 
information (bioinformatics) can give an unprecedented detailed description of both the genome and metabolic activity of bacteria without requiring growth or isolation of bacterial species. Despite these advancements, differences in culture-independent DNA-based approaches and sequencing make direct comparison of studies difficult ${ }^{4,16}$. This is an important consideration for clinicians when evaluating research in this field. Here, we provide a short description of modern molecular biology approaches used in observational studies and clinical trials (Table I), and more detailed reviews can be found elsewhere ${ }^{4,15-17}$. Classical culture techniques can still provide a detailed depiction of a microbial community. However, as the majority of gut bacteria are anaerobic and challenging to cultivate, it is estimated that less than $20-30 \%$ of the gut microbiota have been cultured ${ }^{17}$. This does not mean that all uncultured organisms are unculturable per se, rather that optimal growth conditions have not been designed or discovered ${ }^{17}$.

Culture-independent techniques have the advantage that they can give a more representative view of the gut microbiota and their diversity ${ }^{17}$. They are based on extraction of DNA and amplification of portions of the $16 \mathrm{~S}$ rRNA gene (16S), which is highly conserved among bacterial species but variable in other internal regions of the gene and thus allows species identification ${ }^{15,17}$. In clinical trials, methods such a quantitative PCR (q-PCR), denaturing gradient gel electrophoresis (DGGE), terminal restriction fragment length polymorphism (TRFLP), fluorescence in situ hybridization (FISH), DNA microarrays, and next-generation sequencing of the $16 \mathrm{~S}$ gene or its amplicons have been used ${ }^{17}$. These methods not only provide qualitative and quantitative information on bacterial species, but also on microbial diversity and ordination, and are increasingly being used in clinical studies ${ }^{15,17}$. Still, a level of imprecision in 16S-based microbial classification and the associated sequence data have currently hampered capacity to clearly define which specific microbes might be associated 
with specific diseases, although this is being further developed ${ }^{15,18}$. It has also been argued that traditional measures of diversity in a microbial community are still relatively crude, and to overcome this new diversity profiles are being developed ${ }^{19}$.

The $16 \mathrm{~S}$ sequencing approach is now the most widely used. Although there are many benefits, there are also limitations; mainly that the precision is dependent on whether the proportions of the resulting $16 \mathrm{~S}$ gene sequences accurately reflect the proportion of bacteria in the original sample - as this is affected by copy number variation, PCR primer and amplification bias ${ }^{15}$. Cell lysis during DNA extraction can also lead to variation in taxa e.g. bifidobacteria. The magnitude of these biases varies substantially between studies ${ }^{15,20}$. Another limitation is that $16 \mathrm{~S}$ sequencing does not give any information on the functional capacity, e.g. the metabolic capacity. One way of addressing this is through predictive bioinformatics methods. As the human intestine is a community with several available reference genomes, bioinformatics software packages can be used to predict an approximate metagenome ${ }^{15,17,21}$. This is done by connecting functions of gene products encoded by the most closely related sequenced genomes with observed taxonomic profiles, thereby creating a functional profile ${ }^{4,15,21}$.

Alternatively, metagenome or metatranscriptome sequencing is now being used to attain a functional profile and higher resolution of the composition of bacterial communities (identification to the species and also strain level). This is also known as shotgun sequencing, DNA-seq or RNA-seq and refer to sequencing the entire nucleotide pool isolated from a sample ${ }^{15}$. In contrast to $16 \mathrm{~S}$ studies, this technique also sequences a small amount of human DNA- and also archaea, fungi, and viruses found in a stool sample ${ }^{15,16}$. The latter can add valuable information since other microbes than bacteria may also have a role in forming mucosal immune responses ${ }^{5}$, although less is known about these exposures in the context of 
NCDs and will not be covered in this review. Compared with 16S studies, metagenome studies are more expensive and analysis of the massive amount of data generated requires additional computational expertise ${ }^{16,17}$. Metaproteomic and metabolomic analyses are other emerging methods that further characterize the functional capacities of the microbiome ${ }^{15,16}$.

The site and the nature of sample collection are also important. Most published studies have analyzed microbial communities in stool samples rather than using mucosal biopsies or luminal content analysis, which differ in composition. Although mucosal biopsy samples pose practical and ethical challenges, it is recognized that the mucosal microbiota might be more pertinent for human disease ${ }^{17}$.

\section{Gut microbiota are essential for normal development and regulation; multisystem} effects

The critical role of the gut microbiota in immune development has been well documented in germ free animal models, demonstrating the failure of normal maturation and, in particular, failure of the systemic immune regulatory networks, that result in both allergic and autoimmune phenomena (as reviewed by) ${ }^{5-8}$. Significantly, early experiments clearly demonstrated a critical early developmental "window" during which microbial colonization could induce appropriate maturation of the Th2 response and $\operatorname{IgE}$ regulation, and after which this was no longer possible ${ }^{22}$. More recently, it has been shown that the diversity of colonization is crucial for the development of an immunoregulatory network that protects against IgE induction in the mucosa ${ }^{23}$. It remains unclear if such a "window" exists also in humans, but this is nonetheless consistent with observations that gut microbial exposures in infancy may impact the maturation of mucosal and systemic immune responses in infants 8,24 , 25. 
The proinflammatory and metabolic effects of altering the gut microbiota have also been observed in animal models of obesity ${ }^{6}$. Notably, more subtle manipulation with low doses of antibiotics in early life (at levels likely to be encountered in human food) increased the risk of adiposity, with significant effects on short-chain fatty acid (SCFA) levels, and in the regulation of hepatic metabolism of lipids and cholesterol ${ }^{26}$. Equally fascinating are results from experimental models reporting changes in behaviour and gene expression in the brain following changes in the gut microbiota ${ }^{6,8}$. Possibly less well-known to immunologists, in another aspect of their work in germ-free animals Sudo and colleagues also demonstrated reduced expression of the neuronal growth factor BDNF in the cortex and hippocampus ${ }^{27}$, consistent with patterns seen in depression and anxiety. They also had heightened cortisol stress responses. This shows that without normal bacteria "germ free" animals will develop potentially maladaptive changes in brain function and in endocrine regulation of the stress response through the hypothalamic-pituitary-adrenal (HPA) axis. Critically, these effects can

all be reversed by either giving probiotics, or by "fecal transplant" with normal mouse microbiota ${ }^{27}$. Perhaps of even greater significance, timing was critical - reversal is only possible at an early stage of development. Once the response patterns become established with age, they cannot be readily changed. This is true of both the stress and immune responses, which remain abnormal once they are "committed". It is also consistent with what we know about "critical early periods" for both immune and neural development and the declining plasticity of neural networks with age. Collectively, these findings formed a basis to further explore the role of gut microbiota in early programming of host responses also in humans.

\section{Establishment of the human gut microbiota}

The human gut microbiota evolves through ecological succession with compositional and 
functional changes over the first years of life ${ }^{28}$, eventuating in a relatively stable microbial community ${ }^{4,28}$. This is influenced by interactions between the environment, diet, microbeassociated and host-related factors ${ }^{29,30}$. For the majority of humans, the first postnatal microbial exposures originate from maternal vaginal and perianal microbiota. Shortly after delivery, the gut microbiota of a vaginally delivered (VD) infant resembles that of their mother's vagina ${ }^{31}$. In contrast, infants delivered by caesarean section (CS) initially acquire microbial communities typically found on maternal skin followed by the gradual acquisition of a more complex microbiota - typically more slowly than in VD infants. However there is high individual variability in the patterns of bacterial species, and the timing of acquisition ${ }^{4}$ 28. Even so, across individuals and populations, infant microbiomes generally have a higher proportion of bifidobacteria and lower species richness than adults ${ }^{28}$ and share common functional characteristics - for example, infants typically show metagenomes enriched in genes for simple sugar breakdown and folate synthesis ${ }^{4,28}$. Microorganisms colonizing the gastrointestinal tract are involved in a number of vital processes $5,6,8,29$. With about $70 \%$ of the cellular component of the immune system present as gut-associated lymphoid tissue, the potential for crosstalk between microbiota and the immune system is substantial; and is likely to play a central role in enabling microbial imprinting and immune programming of the newborn microbiota ${ }^{8}$. Recent discoveries that bacterial DNA is present in the newborn's first stool (meconium) ${ }^{32,33}$ and in the feto-placental unit ${ }^{33,34}$ with the placental microbiome profiles being most similar to the oral microbiome ${ }^{34}$, challenges the "sterile womb" paradigm. This suggests that the imprinting of gut microbiota may commence already in utero and is then further shaped by postnatal exposures. ${ }^{8,30,33}$

\section{Environmental factors impact gut microbiota establishment in infants}

In addition to $\mathrm{CS}{ }^{31,35-37}$, antibiotics to the mother or infant ${ }^{29}$, breastfeeding ${ }^{35,37}$ and 
introduction of solid foods ${ }^{28}$ influence establishment of the gut microbiota. Infants born by CS have a higher incidence of respiratory distress ${ }^{38}$ and appear to be at higher risk for developing asthma and atopy ${ }^{39}$, obesity ${ }^{40}$ and type 1 diabetes ${ }^{41}$. It has been hypothesized that delayed and aberrant intestinal colonization might contribute to this risk conferred by CS. Recent studies that have applied DNA-based approaches have demonstrated perturbations in infant gut microbiomes with lower diversity of Bacteroidetes ${ }^{36}$ and abundance of the genus Bacteroides in CS-delivered infants ${ }^{35-37}$ suggesting that dysbiosis may, at least partly, contribute. Beyond its direct impact on microbial exposure, CS requires antibiotic treatment and can delay onset of breastfeeding, which can lead to further ecological perturbations ${ }^{35-37}$. Retrospective studies have reported antibiotic treatment in early life to be associated with increased risk of asthma, although the results may still be influenced by reverse causation or confounding by indication ${ }^{42}$.

The gut microbiota evolves over the preschool years with an adult-like profile emerging by 34 years of age in humans ${ }^{4,28}$. Established microbiota of adult humans can be divided into different "enterotypes" based on clusters of predominant bacterial genera in the gut microbiome ${ }^{43}$. As yet, it is not clear how these enterotypes are formed, but this process is likely to be influenced by diet and other environmental factors $4,43,44$. Recently, it has also been argued that there are gradients of key genera rather than distinct clusters ${ }^{4,45,46}$.

\section{An aberrant gut microbiome in early and late onset NCDs}

Changes in the gut microbiome are the inevitable result of complex changes in both our nutritional patterns and our built environment. The consequences of early environmental change are evident in the dramatic rise in early onset inflammatory NCDs (such as allergic disease). Effects on the developing immune system are consistent with the "hygiene hypothesis" which initially focused on declining exposures to 'external' infectious 
microorganisms 9 . A more recent focus on the "gut microbial deprivation hypothesis" has shifted the emphasis to the importance of gut microbial exposures for normal immune development and regulation ${ }^{11}$. This concept is supported by culture-independent DNA-based studies demonstrating associations between reduced gut microbiota diversity and early onset NCDs including atopy ${ }^{47}$, eczema ${ }^{37,48-50}$, and asthma ${ }^{51}$. However this has not been seen in all studies ${ }^{52}$.

Also in intestinal inflammatory disease, several studies have now reported dysbiosis to be associated with IBD ${ }^{53}$ and celiac disease ${ }^{54}$. Increased gut permeability and intestinal inflammation with impaired immune-regulatory mechanisms have been shown in children with allergic disease ${ }^{55}$, and also in children with type 1 diabetes ${ }^{56}$. Consistent with reports of dysbiosis in children with allergic manifestations, an aberrant gut microbiome has been associated with type 1 diabetes 57, 58. 16S-sequencing revealed differences in the gut microbiome in children with signs of ß-cell autoimmunity compared to healthy children of the same age and sex, with similar feeding history and genetic risk ${ }^{57}$. In particular, children with B-cell autoimmunity had lower levels of bifidobacteria, which normally enhance intestinal epithelial barrier function and suppress inflammation. For comparison, using DGGE-PCR and q-PCR, dysbiosis was observed in diabetic children with the number of bifidobacteria, lactobacilli and the Firmicutes/Bacteroidetes ratio correlating negatively with plasma glucose levels whereas numbers of clostridia displayed a positive correlation ${ }^{58}$.

It is also suggested that the early microbial environment drives more sustained predisposition to low-grade inflammation into adulthood and the propensity for later onset NCDs ${ }^{59}$. In highincome countries baseline C-reactive protein (CRP), as a measure of inflammatory state, is higher than in traditional environments, and a risk factor for $\mathrm{CVD}^{60}$, type 2 diabetes ${ }^{61}$, and 
have higher "all cause" mortality ${ }^{62}$. A significant component of the risk of these disorders is programmed during early development ${ }^{63}$, and many children already exhibit the inflammatory antecedents of cardio-metabolic risk ${ }^{64}$. It has therefore been hypothesized that the early environment and early patterns of microbial exposure may influence the dynamics of inflammation in adulthood ${ }^{59}$. While there has been a focus on infectious exposures, the commensal gut microbiota, which are also heavily influenced by early nutrition, are likely to play an even more important role in developing immune and metabolic homeostasis. Some support for this was recently reported in mice, where low-dose penicillin (LDP) in early life transiently impacted gut microbiota, affected ileal expression of genes involved in immunity and induced long-term metabolic perturbations ${ }^{65}$. Notably, the combination of LDP and dietary excess further increased fat mass.

Although diet and a sedentary lifestyle are important contributors to the obesity epidemic, there is growing recognition that gut microbiota regulate metabolic function and energy balance ${ }^{6}$. Studies in obese adults reported reduced diversity, an increase in Firmicutes and a corresponding decrease in Bacteroidetes, although this was not seen in all studies 4, 6, 43. Recently, a tendency towards decreased gut microbiota diversity in overweight/obese children assessed by q-PCR and T-RFLP was reported ${ }^{66}$. Using FISH, reduced numbers of bifidobacteria in infancy have also been shown to precede development of obesity ${ }^{67}$. Aberrations in the gut microbiota may also have implications for obesity-associated NCDs. In a recent report, adults with reduced gut microbial richness had higher overall adiposity, insulin resistance, dyslipidaemia and a more pronounced inflammatory phenotype than adults with higher gut microbial richness ${ }^{68}$. Dysbiosis has even been associated with neurodevelopment and mental health in a series of experimental models ${ }^{6}$. Whether microbial 
variation is the cause or effect of these diseases is still the subject of conjecture, but this highlights the multisystem effects of the microbiome.

\section{Modulation of the gut microbiota for treatment and prevention of NCDs}

Collectively, this has led to intense interest in strategies to correct dysbiosis for treatment purposes and to favorably impact intestinal colonization to prevent NCDs (Figure I).

\section{Probiotics}

The most widely used approach has been to administer probiotics ${ }^{69}$, (Table II). In most studies, single or several strains of lactobacilli and bifidobacteria have been used for treatment and prevention of allergic disease; the demonstrated effect of one probiotic strain cannot be extrapolated to another strain. Some probiotics exert immunomodulatory effects, mostly shown in experimental models but also in human intervention studies ${ }^{8,70}$. Mechanistic effects are thought to be mediated by Toll-like-receptors (TLR) to promote Th-1 cell differentiation, through enhanced production of IL-10, TGF- 3 and IgA, inhibition of antigen-induced T-cell activation and suppression of TNF ${ }^{8,70}$. The timing of probiotics for promoting immune tolerance appears critical ${ }^{8}$, and a combination of pre and postnatal probiotic supplementation for allergy prevention (namely eczema) has shown the most consistent benefit, although their routine use cannot be recommended $8,30,70$. To date, reports on later onset allergic manifestations e.g. respiratory allergic disease from initiated cohorts are limited and need to be prospectively collected and reported ${ }^{8,30,70}$. If prenatal microbial exposure enhances the preventive effect, as also suggested by epidemiological ${ }^{71,72}$ and experimental studies ${ }^{73}$, starting supplementation in the second trimester of pregnancy, when circulating fetal $\mathrm{T}$ cells have developed, may be more effective ${ }^{8}$. This may include effects on asthma development, which so far probiotic interventions have failed to prevent ${ }^{74-80}$. Using non-conventional probiotics such as butyrate and proprionate producers, immunomodulatory strains of 
bacteroides ${ }^{8,30}$ or clostridia ${ }^{81}$ might also induce stronger effects. Another area to explore is that of probiotic treatment to CS-delivered infants, as data suggest that they might benefit the $\operatorname{most}^{82}$.

The preventive effects of probiotics on other NCDs, would be highly interesting to evaluate, but their low incidence and/or delayed onset compared with allergic diseases make such studies challenging to perform. Some probiotics have been demonstrated to exert beneficial metabolic effects in experimental models ${ }^{83}$ and in human intervention studies ${ }^{84-87}$. There is also growing appreciation that probiotics may have a role in gut-brain function and CNSrelated conditions, (as reviewed by) ${ }^{88}$. However, more research is needed for the mechanistic understanding of probiotics and as of yet, probiotics do not have an established role in the treatment or prevention of any NCD. Many meta-analyses of clinical trials using probiotics have been carried out, however, there has been substantial heterogeneity in several aspects of these studies ${ }^{1}$. If we are to translate findings from conducted studies into recommendations in clinical practice, there is need for a more standardized approach using harmonized protocols and outcome measures in clinical trials ${ }^{8,70}$.

\section{Dietary fiber and prebiotics}

Observational studies have reported an association between the high fat/low fiber Westernized diet and the prevalence of many NCDs, including allergic disease ${ }^{89}$. With these data in mind, modulation of the dietary substrate of gut microbiota (Table II) may be part of strategies for the prevention and treatment of NCDs. Dietary fiber pass through the upper intestine and are fermented by large bowel anaerobic microbiota to produce short-chain fatty acids (SCFAs) ${ }^{90}$. SCFAs promote gut epithelial integrity and exert immune effects including stimulation of G-protein-coupled receptors, promotion of innate (TLR2) immune responses, and induction of $\mathrm{T}$ regulatory cells in the colon ${ }^{90}$. 
In experimental models, switching from a high to low fiber diet induces dramatic changes in gut microbiota composition; for example, a decrease in gut bacteria of the Bacteroidetes phylum ${ }^{90}$. Concordantly, infants in rural Africa, where mothers and infants have a traditional diet very high in fermentable carbohydrates, have substantially higher levels of Bacteroidetes and SCFAs in stool compared with infants from Europe, where mothers and infants have a Western diet ${ }^{44}$. In relation to early onset NCDs, there is preliminary evidence that feeding prebiotics (Table II), from early infancy may prevent eczema but these findings are yet to be confirmed ${ }^{8,30,91}$. In the most recent Cochrane review ${ }^{91}$, including 1428 infants at high risk of allergic disease, prebiotics added to infant feeds reduced the risk of eczema (risk ratio 0.68, $95 \%$ CI 0.48 to 0.97 ), with no effect on any other allergic outcomes.

There are also clinical trials that have assessed prebiotics for metabolic outcomes. In overweight adults, treatment with galactooligosaccharides induced "favorable" changes in gut microbial composition, increased secretory $\operatorname{IgA}(\operatorname{sgA})$, reduced inflammation and measures of the metabolic syndrome ${ }^{92}$. Notably, the combination of a healthy dietary intervention (increased fiber/reduced fat) and probiotics in pregnancy decreased the risk of gestational diabetes compared with the healthy dietary intervention alone or no intervention ${ }^{87}$. Either alone, or in combination, dietary approaches may be a useful tool for gut microbiota modulation in both the treatment and prevention of NCDs. However, the effects of dietary modulation on gut microbiota and host response appear highly individual and difficult to foresee. Interestingly, in a proof of concept study combining microbiome data sets from different dietary intervention studies in obese adults, clostridial species in particular, indicated the amenability of the gut microbiota to dietary modulation, which in turn was associated with the host's lipid metabolism ${ }^{93}$. 


\section{Fecal microbiota transplantation}

There has been emerging interest in fecal microbiota transplantation (FMT) (Table II) in both the treatment and prevention of NCDs ${ }^{94}$. It was first employed in the treatment of Clostridium difficile (C. difficile) diarrhea with a high rate of clinical resolution and no observed adverse events, although these initial trials were not controlled ${ }^{95}$. The principle of FMT for this indication is predicated on the concept that antibiotic therapy (repeated courses or overuse of broad spectrum antibiotics) disrupts the normal ecology allowing colonization of $C$. difficile (Fig II). FMT offers both an investigational tool in rodent models to study the role of microbes in disease development and treatment response ${ }^{6}$, as well as a new therapeutic intervention that has gained credibility in the clinical world following the publication of the first RCT demonstrating the effectiveness of FMT for treatment of antibiotic resistant $C$. difficile diarrhea ${ }^{96}$. The authors also demonstrated a significant increase in Bacteroidetes species and Clostridium clusters IV and XIVa, and a decrease in Proteobacteria species in line with healthy donor profiles.

Despite the lack of clear evidence whether microbial variation is the cause or effect of IBD, there are now several trials of FMT for treatment of IBD with modest results, although no controlled trials have yet been published ${ }^{94}$. FMT might be a future treatment option for many conditions, however, a truly controlled trial design might consider autologous versus allogeneic fecal transplant to ensure there is not a colonoscopy or placebo effect. There are also many recipient and donor factors to consider (Table III). Age is an important factor for both the donor and the recipient as there is significant increase in diversity and stability of gut microbiota over the first years of life ${ }^{4,28}$. Compositional differences may affect susceptibility to disease, but also response to treatment. Factors that might influence the composition of the donor sample include diet, antibiotics/probiotics and a range of environmental exposures, as 
well as underlying disease status ${ }^{94}$. From a practical, clinical perspective the route of administration is important and at least for the treatment of $C$. difficile, colonoscopic and nasogastric administration appears similarly effective ${ }^{97}$, although a higher stool volume was used for FMT in the colonoscopy group. Notably, standardized partially purified and frozen fecal microbiota might be just as effective as the current fresh harvest approach ${ }^{98}$, which might facilitate its clinical use.

\section{Future directions}

While NCDs represent a wide range of diseases we can see common threads that trace back to increased tendency of inflammation, driven by virtually inseparable changes in nutrition and the gut microbiota. The end result of the inflammatory and metabolic changes might vary with genetics ${ }^{2}$, epigenetics ${ }^{63}$, the overall biodiversity ${ }^{10,99}$ and other risk factors, this provides an attractive shared explanation for why so many of these inflammatory conditions have risen during the same time period, under the influence of the same environmental changes. If we are to stand a better chance of solving the complex pathogenesis of NCDs and to understand the role of gut microbiota in this process, there is a call for interdisciplinary approaches, working collaboratively in networks ${ }^{1,8}$. With standardized outcomes and methodologies we will be better apt to address current knowledge gaps (Table III):

1) Research should be focused on the ecological and functional properties of "a healthy gut microbiome"; results from the Human Microbiome Project and MetaHit are anticipated to provide more insight 2) Strategies to improve gut colonization patterns need to be developed since they may have life-long influences on health 3) Although dysbiosis and reduced diversity is centrally implicated in many NCDs, it still remains to be determined if microbial variation is the cause or effect 4) To overcome potential confounding, longitudinal studies 
using the same protocols and methodological platforms are needed 5) Looking at the bacterial components of the microbiome might be overly simplistic and should ultimately include other aspects of the microbiome 6) A research priority should be the development of microbiota signatures in specific disease states 7) Ultimately, these can then be used in clinical practice for improved diagnostic, treatment and prevention strategies that may include optimized dietary interventions, prebiotics, non-conventional indigenous gut bacteria as "nextgeneration probiotics", and FMT. Such multidisciplinary and integrative approaches may ultimately lead to improved strategies to overcome the disease epidemics of modern civilizations.

\section{What do we know}

- Experimental models demonstrate that gut microbiota exert physiological, metabolic and nutritional functions, and are vital for normal immune development and regulation

- Observational studies show variations of gut microbiota and reduced microbial diversity to be associated with various NCDs such as eczema, allergic rhinitis, asthma, autoimmune disease and obesity

- Meta-analyses of clinical trials using probiotics for allergy prevention have demonstrated a reduced incidence of eczema, but not any other allergic outcomes

- Meta-analyses of a limited number of clinical trials using prebiotics for allergy prevention suggest a reduction of eczema, but only in high-risk populations

- Fecal microbiota transplantation regulates inflammation in experimental models

\section{What is still unknown?}

- If the dysbiosis and reduced microbial diversity seen in many NCDs is causal

- How probiotics mediate their clinical effects in NCDs 
- If prebiotics has a role in prevention of allergic disease in high-risk and low-risk populations

- What the long term effects of fecal microbiota transplantation are in humans- clinical benefit as well as safety aspects 
Table I. Example of culture-independent methods used in studies assessing the role of gut microbiota in non-communicable diseases (NCDs)

\begin{tabular}{|c|c|c|c|c|}
\hline Method & Explanation & Benefits & Weaknesses & \multirow[b]{2}{*}{$\begin{array}{l}\text { Insights from studies } \\
\text { using the method in the } \\
\text { context of NCDs } \\
\text { Mucosal biopsies from } \\
\text { patients with } \\
\text { inflammatory bowel } \\
\text { disease revealed } \\
\text { abnormal gastrointestinal } \\
\text { microbiota composition } \\
\text { depleted of commensal } \\
\text { bacteria (Frank et al, } \\
\text { 2007); } \\
\text { Delivery mode and } \\
\text { exposure to older } \\
\text { siblings affected gut } \\
\text { microbiota composition } \\
\text { assessed in infant stool } \\
\text { samples and impacted } \\
\text { subsequent risk of } \\
\text { allergic disease (van } \\
\text { Nimwegen et al, 2011, } \\
\text { Penders et al, 2013) }\end{array}$} \\
\hline q-PCR & $\begin{array}{l}\text { Amplification } \\
\text { and quantification } \\
\text { of } 16 \mathrm{~S} \text { rRNA. }\end{array}$ & $\begin{array}{l}\text { Confirms } \\
\text { phylogenetic } \\
\text { identity, } \\
\text { quantitative, } \\
\text { quick. }\end{array}$ & $\begin{array}{l}\text { Cannot identify } \\
\text { unknown } \\
\text { species, PCR } \\
\text { bias. }\end{array}$ & \\
\hline DGGE & $\begin{array}{l}\text { Gel separation } \\
\text { of } 16 \mathrm{~S} \text { rRNA } \\
\text { amplicons using } \\
\text { denaturant. }\end{array}$ & $\begin{array}{l}\text { Semi- } \\
\text { quantitative, } \\
\text { bands can be } \\
\text { excised for } \\
\text { additional } \\
\text { analysis, } \\
\text { quick. }\end{array}$ & $\begin{array}{l}\text { Cannot confirm } \\
\text { phylogenetic } \\
\text { identification, } \\
\text { PCR bias. }\end{array}$ & $\begin{array}{l}\text { Studies combining } \\
\text { DGGE with q-PCR } \\
\text { reported reduced } \\
\text { microbial diversity in } \\
\text { stool samples at } 1 \text { and } 12 \\
\text { months of age in } \\
\text { children developing } \\
\text { sensitization, allergic } \\
\text { rhinitis and blood } \\
\text { eosinophilia but not } \\
\text { eczema or asthma at } \\
\text { school age (Bisgaard et } \\
\text { al, 2011); } \\
\text { and reported } \\
\text { compositional changes } \\
\text { in stool samples of } \\
\text { diabetic compared with } \\
\text { healthy children. The } \\
\text { numbers of } \\
\text { bifidobacteria and } \\
\text { lactobacilli, and the } \\
\text { Firmicutes/Bacteroidetes } \\
\text { ratio correlated } \\
\text { negatively with plasma }\end{array}$ \\
\hline
\end{tabular}




\begin{tabular}{|c|c|c|c|c|}
\hline & & & & $\begin{array}{l}\text { glucose levels whereas } \\
\text { numbers of clostridia } \\
\text { displayed a positive } \\
\text { correlation in diabetic } \\
\text { children (Murri et al, } \\
\text { 2013) } \\
\end{array}$ \\
\hline T-RFLP & $\begin{array}{l}\text { Amplification of } \\
\text { fluorescently } \\
\text { labeled primers, } \\
\text { followed by } \\
\text { digestion of the } \\
16 \mathrm{~S} \text { rRNA } \\
\text { amplicon by } \\
\text { restriction } \\
\text { enzymes. } \\
\text { Separation } \\
\text { of digested } \\
\text { fragments } \\
\text { by gel } \\
\text { electrophoresis. }\end{array}$ & $\begin{array}{l}\text { Semi- } \\
\text { quantitative, } \\
\text { quick, cheap. }\end{array}$ & $\begin{array}{l}\text { Cannot confirm } \\
\text { phylogenetic } \\
\text { identification, } \\
\text { PCR bias, weak } \\
\text { resolution. }\end{array}$ & $\begin{array}{l}\text { Reduced gut microbial } \\
\text { diversity in stool } \\
\text { samples at } 1 \text { week of age } \\
\text { was associated with } \\
\text { increased risk of } \\
\text { subsequent eczema } \\
\text { (Ismail et al, 2012) } \\
\text { Combining T-RFLP with } \\
\text { q-PCR revealed that the } \\
\text { concentration of } \\
\text { Enterobacteriaceae was } \\
\text { higher in stool samples } \\
\text { of obese/overweight } \\
\text { children compared with } \\
\text { normal weight children } \\
\text { (Karlsson et al, 2012) }\end{array}$ \\
\hline FISH & $\begin{array}{l}\text { Hybridization of } \\
\text { fluorescently } \\
\text { labeled } \\
\text { oligonucleotide } \\
\text { probes with } \\
\text { complementary } \\
\text { target } 16 \mathrm{~S} \text { rRNA } \\
\text { sequences. } \\
\text { Fluorescence } \\
\text { enumerated by } \\
\text { flow cytometry. }\end{array}$ & $\begin{array}{l}\text { Confirms } \\
\text { phylogenetic } \\
\text { identity, } \\
\text { semi- } \\
\text { quantitative, } \\
\text { no PCR bias. }\end{array}$ & $\begin{array}{l}\text { Dependent on } \\
\text { probe sequences } \\
\text { and cannot } \\
\text { identify } \\
\text { unknown } \\
\text { species. }\end{array}$ & $\begin{array}{l}\text { Bifidobacterial numbers } \\
\text { in stool samples } \\
\text { collected at } 6 \text { and } 12 \\
\text { months of age were } \\
\text { higher in children that } \\
\text { remained normal weight } \\
\text { at school age } \\
\text { (Kalliomäki et al, 2008) }\end{array}$ \\
\hline $\begin{array}{l}\text { DNA } \\
\text { micro- } \\
\text { arrays }\end{array}$ & $\begin{array}{l}\text { Hybridization of } \\
\text { fluorescently } \\
\text { labeled } \\
\text { oligonucleotide } \\
\text { probes with } \\
\text { complementary } \\
\text { nucleotide } \\
\text { sequences. Laser } \\
\text { used to detect } \\
\text { fluorescence. }\end{array}$ & $\begin{array}{l}\text { Confirms } \\
\text { phylogenetic } \\
\text { identity, } \\
\text { semi- } \\
\text { quantitative, } \\
\text { quick. }\end{array}$ & $\begin{array}{l}\text { Cross } \\
\text { hybdridization, } \\
\text { PCR bias, may } \\
\text { miss species } \\
\text { present in low } \\
\text { levels. }\end{array}$ & $\begin{array}{l}\text { Children with eczema } \\
\text { had higher total } \\
\text { microbial diversity and } \\
\text { reduced abundance of } \\
\text { Bacteroidetes in stool } \\
\text { samples at } 18 \text { months of } \\
\text { age compared with } \\
\text { healthy controls (Nylund } \\
\text { et al, 2013) }\end{array}$ \\
\hline $\begin{array}{l}\text { Sequen- } \\
\text { cing } \\
\text { of } 16 S \\
\text { rRNA } \\
\text { ampli- }\end{array}$ & $\begin{array}{l}\text { Massive parallel } \\
\text { sequencing of } \\
\text { partial } 16 \mathrm{~S} \\
\text { rRNA amplicons. }\end{array}$ & $\begin{array}{l}\text { Confirms } \\
\text { phylogenetic } \\
\text { identity but } \\
\text { not at species } \\
\text { level, }\end{array}$ & $\begin{array}{l}\text { Labor-intensive, } \\
\text { expensive, PCR } \\
\text { and } \\
\text { amplification } \\
\text { bias. Need for }\end{array}$ & $\begin{array}{l}\text { Reduced total microbial } \\
\text { diversity and diversity of } \\
\text { Bacteroidetes in stool } \\
\text { samples at } 1 \text { month of } \\
\text { age was associated with }\end{array}$ \\
\hline
\end{tabular}




\begin{tabular}{|c|c|c|c|c|}
\hline cons & & $\begin{array}{l}\text { quantitative, } \\
\text { quick, } \\
\text { identifies } \\
\text { unknown } \\
\text { bacteria. }\end{array}$ & $\begin{array}{l}\text { computational } \\
\text { expertise. }\end{array}$ & $\begin{array}{l}\text { increased risk of } \\
\text { subsequent IgE- } \\
\text { associated eczema } \\
\text { (Abrahamsson et al, } \\
\text { 2012); reduced total } \\
\text { diversity was also } \\
\text { associated with } \\
\text { increased risk of asthma } \\
\text { but not allergic rhinitis at } \\
\text { school age } \\
\text { (Abrahamsson et al, } \\
\text { 2014) } \\
\text { A low abundance of } \\
\text { lactate- and butyrate- } \\
\text { producing species in } \\
\text { stool samples was } \\
\text { associated with } \beta \text {-cell } \\
\text { autoimmunity (de } \\
\text { Goffau et al, 2013 ); }\end{array}$ \\
\hline $\begin{array}{l}\text { Meta- } \\
\text { genome } \\
\text { sequen- } \\
\text { cing }\end{array}$ & $\begin{array}{l}\text { Massive parallel } \\
\text { sequencing of the } \\
\text { whole genome. }\end{array}$ & $\begin{array}{l}\text { Confirms } \\
\text { phylogenetic } \\
\text { identity, } \\
\text { quantitative. }\end{array}$ & $\begin{array}{l}\text { Most expensive } \\
\text { method, } \\
\text { generates large } \\
\text { amounts of data } \\
\text { that need } \\
\text { computational } \\
\text { expertise. }\end{array}$ & $\begin{array}{l}\text { Compared with adults } \\
\text { with high bacterial } \\
\text { richness in stool } \\
\text { samples, adults with low } \\
\text { bacterial richness had } \\
\text { more marked overall } \\
\text { adiposity, insulin } \\
\text { resistance and } \\
\text { dyslipidaemia in } \\
\text { association with a more } \\
\text { pronounced } \\
\text { inflammatory phenotype } \\
\text { (Le Chatelier et al, 2013) }\end{array}$ \\
\hline
\end{tabular}

q-PCR- quantitative PCR, DGGE- denaturing gradient gel electrophoresis, T-RFLP- terminal restriction fragment length polymorphism, FISH- fluorescence in situ hybridization

Adapted from Fraher MH et al, Techniques used to characterize the gut microbiota: a guide for the clinician. Nat. Rev.Gastroenterol. Hepatol 2012; 9:313. Reprinted with permission from Macmillan Publishers Limited. 
West 24

Table II. Treatment strategies for gut microbiota modulation in non-communicable diseases

(NCDs)

\begin{tabular}{|c|c|c|}
\hline Treatment & Definition & References \\
\hline Probiotics & $\begin{array}{l}\text { "Live microorganisms which } \\
\text { when administered in adequate } \\
\text { amounts confer a health benefit } \\
\text { on the host" (69) }\end{array}$ & $\begin{array}{l}\text { Bertelsen et al, 2014 } \\
\text { Kalliomäki et al, } 2007 \\
\text { Jensen et al, 2012 } \\
\text { West et al, 2013 } \\
\text { Abrahamsson et al, } 2013 \\
\text { Wickens et al, 2013 } \\
\text { Loo et al, 2014 } \\
\text { Azad et al, 2013 } \\
\text { Kuitunen et al, } 2009 \\
\text { Wang et al, 2014 } \\
\text { Chorell et al, 2013 } \\
\text { Kadooka et al, 2010 } \\
\text { Luoto et al, 2010 }\end{array}$ \\
\hline Prebiotics & $\begin{array}{l}\text { Non-digestible fermentable } \\
\text { oligosaccharides }\end{array}$ & $\begin{array}{l}\text { Thorburn et al, } 2014 \\
\text { Osborn and Sinn, } 2013 \\
\text { Vulevic et al, } 2013\end{array}$ \\
\hline Dietary fiber & $\begin{array}{l}\text { Non-digestible carbohydrates of } \\
\text { plant origin }\end{array}$ & Thorburn et al, 2014 \\
\hline $\begin{array}{l}\text { Fecal microbiota } \\
\text { transplantation }\end{array}$ & $\begin{array}{l}\text { Transplantation of fecal bacteria } \\
\text { from a healthy donor to a } \\
\text { recipient }\end{array}$ & $\begin{array}{l}\text { Smits et al, } 2013 \\
\text { Kassam et al, } 2013 \\
\text { van Nood et al } 2013 \\
\text { Postigo et al, 2012 } \\
\text { Hamilton et al, 2013 }\end{array}$ \\
\hline
\end{tabular}


Table III. Current knowledge gaps of the role of gut microbiota in non-communicable diseases (NCDs) and suggestions for further work

\begin{tabular}{|c|c|c|}
\hline Current situation & References & Future prospects \\
\hline $\begin{array}{l}\text { The "healthy gut } \\
\text { microbiome" still not } \\
\text { clearly defined. }\end{array}$ & $\begin{array}{l}\text { Lozupone et al, } 2012 \\
\text { Gevers et al, } 2012 \\
\text { Aagard et al, } 2013 \\
\text { West et al, } 2014\end{array}$ & $\begin{array}{l}\text { There is need for further } \\
\text { characterization of both gut } \\
\text { microbial ecology and the } \\
\text { functional activities of the } \\
\text { gut microbiota. }\end{array}$ \\
\hline $\begin{array}{l}\text { Dysbiosis and/or reduced } \\
\text { gut microbial diversity have } \\
\text { been reported in human } \\
\text { studies in various NCDs- } \\
\text { cause or effect? }\end{array}$ & $\begin{array}{l}\text { Gosalbes et al, 2013 } \\
\text { Penders et al, } 2013 \\
\text { Bisgaard et al, 2011 } \\
\text { Abrahamsson et al, } 2012 \text { and } 2014 \\
\text { Ismail et al, 2012 } \\
\text { van Nimwegen et al, } 2011 \\
\text { Nylund et al, 2013 } \\
\text { Frank et al, 2007 } \\
\text { Cheng et al, 2013 } \\
\text { de Goffau et al, 2013 } \\
\text { Murri et al, 2013 } \\
\text { Karlsson et al, 2012 } \\
\text { Kalliomäki et al, 2008 } \\
\text { Le Chatelier et al, 2013 } \\
\text { Korpela et el, 2014 }\end{array}$ & $\begin{array}{l}\text { Multidisciplinary, } \\
\text { integrative approaches and } \\
\text { careful monitoring of gut } \\
\text { microbiota, other } \\
\text { environmental exposures } \\
\text { and host-specific factors } \\
\text { before onset of disease will } \\
\text { further our understanding. }\end{array}$ \\
\hline $\begin{array}{l}\text { Potential confounding in } \\
\text { observational studies } \\
\text { because of lack of } \\
\text { information on all } \\
\text { exposures that may have } \\
\text { affected the gut microbiota } \\
\text { and/or short period of } \\
\text { observation. }\end{array}$ & $\begin{array}{l}\text { Lozupone et al, } 2012 \\
\text { Gevers et al, } 2012 \\
\text { Aagard et al, } 2013\end{array}$ & $\begin{array}{l}\text { Longitudinal studies in } \\
\text { multiple settings using the } \\
\text { same protocols and } \\
\text { methodological platforms, } \\
\text { which may enable direct } \\
\text { comparison of studies. }\end{array}$ \\
\hline $\begin{array}{l}\text { Current gut microbiota } \\
\text { modulation strategies for } \\
\text { treatment and prevention } \\
\text { are preliminary, variable or } \\
\text { limited in magnitude. }\end{array}$ & $\begin{array}{l}\text { Fiocchi et al, 2012 } \\
\text { West et al, 2014 } \\
\text { Ellwood et al, 2012 } \\
\text { Osborn and Sinn, } 2013 \\
\text { Smits et al, 2013 }\end{array}$ & $\begin{array}{l}\text { Monitoring of long-term } \\
\text { effects and safety, especially } \\
\text { for fecal microbiota } \\
\text { transplantation (FMT), is } \\
\text { needed. Development and } \\
\text { evaluation of optimized } \\
\text { dietary interventions, } \\
\text { prebiotics, non-conventional } \\
\text { indigenous gut bacteria as } \\
\text { "next-generation } \\
\text { probiotics", and FMT. }\end{array}$ \\
\hline
\end{tabular}

NCDs- non-communicable diseases, FMT- fecal microbiota transplantation 


\section{Figure legends}

\section{Fig I.}

Dysbiosis- an "imbalance in the structure and/or function of the microbiota that leads to disruption of host-microorganism homeostasis" ${ }^{6}$ has been implicated in a broad range of inflammatory disease states. There is also suggestive evidence that changes in gut microbiota have implications for cognitive and mental health dysfunction, and stress responses. These diverse multisystem influences have sparked interest in strategies to favorably modulate the gut microbiota to attain homeostasis.

\section{Fig II.}

Overuse or repeated courses of broadspectrum antibiotics disrupts the normal ecology allowing colonization of Clostridium difficile (C.difficile) leading to dysbiosis. Fecal microbiota transplantation (FMT) with feces from a healthy donor administered via A) colonoscopic or B) nasogastric routes restores microbial ecology and resolves inflammation. 


\section{References}

1. Prescott SL. Early-life environmental determinants of allergic diseases and the wider pandemic of inflammatory noncommunicable diseases. J Allergy Clin Immunol 2013; 131:23-30.

2. Ke X. Presence of multiple independent effects in risk loci of common complex human diseases. Am J Hum Genet 2012; 91:185-92.

3. Qin J, Li R, Raes J, Arumugam M, Burgdorf KS, Manichanh C, et al. A human gut microbial gene catalogue established by metagenomic sequencing. Nature 2010; 464:59-65.

4. Lozupone CA, Stombaugh JI, Gordon JI, Jansson JK, Knight R. Diversity, stability and resilience of the human gut microbiota. Nature 2012; 489:220-30.

5. Renz H, Brandtzaeg P, Hornef M. The impact of perinatal immune development on mucosal homeostasis and chronic inflammation. Nat Rev Immunol 2012; 12:9-23.

6. Sommer F, Bäckhed F. The gut microbiota--masters of host development and physiology. Nat Rev Microbiol 2013; 11:227-38.

7. Garn H, Neves JF, Blumberg RS, Renz H. Effect of barrier microbes on organ-based inflammation. J Allergy Clin Immunol 2013; 131:1465-78.

8. West CE, Jenmalm MC, Prescott SL. The gut microbiota and its role in the development of allergic disease: a wider perspective. Clin Exp Allergy 2014, epub ahead of print.

9. Strachan DP. Hay fever, hygiene, and household size. BMJ 1989; 299:1259-60.

10. Rook GA. Regulation of the immune system by biodiversity from the natural environment: an ecosystem service essential to health. Proc Natl Acad Sci U S A 2013; 110:18360-7.

11. Wold AE. The hygiene hypothesis revised: is the rising frequency of allergy due to changes in the intestinal flora? Allergy 1998; 53:20-5.

12. Medzhitov R. Origin and physiological roles of inflammation. Nature 2008; 454:42835 .

13. Gevers D, Knight R, Petrosino JF, Huang K, McGuire AL, Birren BW, et al. The Human Microbiome Project: a community resource for the healthy human microbiome. PLoS Biol 2012; 10:e1001377.

14. Aagaard K, Petrosino J, Keitel W, Watson M, Katancik J, Garcia N, et al. The Human Microbiome Project strategy for comprehensive sampling of the human microbiome and why it matters. FASEB J 2013; 27:1012-22.

15. Morgan XC, Huttenhower C. Meta'omic analytic techniques for studying the intestinal microbiome. Gastroenterology 2014; 146:1437-48 e1.

16. Goodrich JK, Di Rienzi SC, Poole AC, Koren O, Walters WA, Caporaso JG, et al. Conducting a Microbiome Study. Cell 2014; 158:250-62.

17. Fraher MH, O'Toole PW, Quigley EM. Techniques used to characterize the gut microbiota: a guide for the clinician. Nat Rev Gastroenterol Hepatol 2012; 9:312-22.

18. Jumpstart Consortium Human Microbiome Project Data Generation Working G. Evaluation of 16S rDNA-based community profiling for human microbiome research. PLoS One 2012; 7:e39315.

19. Doll HM, Armitage DW, Daly RA, Emerson JB, Goltsman DS, Yelton AP, et al. Utilizing novel diversity estimators to quantify multiple dimensions of microbial biodiversity across domains. BMC Microbiol 2013; 13:259.

20. Lee CK, Herbold CW, Polson SW, Wommack KE, Williamson SJ, McDonald IR, et al. Groundtruthing next-gen sequencing for microbial ecology-biases and errors in community structure estimates from PCR amplicon pyrosequencing. PLoS One 2012; 
7:e44224.

21. Langille MG, Zaneveld J, Caporaso JG, McDonald D, Knights D, Reyes JA, et al. Predictive functional profiling of microbial communities using 16S rRNA marker gene sequences. Nat Biotechnol 2013; 31:814-21.

22. Sudo N, Sawamura S, Tanaka K, Aiba Y, Kubo C, Koga Y. The requirement of intestinal bacterial flora for the development of an IgE production system fully susceptible to oral tolerance induction. J Immunol 1997; 159:1739-45.

23. Cahenzli J, Koller Y, Wyss M, Geuking MB, McCoy KD. Intestinal microbial diversity during early-life colonization shapes long-term IgE levels. Cell Host Microbe 2013; 14:559-70.

24. Sjögren YM, Tomicic S, Lundberg A, Böttcher MF, Björkstén B, SverremarkEkström E, et al. Influence of early gut microbiota on the maturation of childhood mucosal and systemic immune responses. Clin Exp Allergy 2009; 39:1842-51.

25. Wang S, Hibberd ML, Pettersson S, Lee YK. Enterococcus faecalis from healthy infants modulates inflammation through MAPK signaling pathways. PLoS One 2014; 9:e97523.

26. Cho I, Yamanishi S, Cox L, Methe BA, Zavadil J, Li K, et al. Antibiotics in early life alter the murine colonic microbiome and adiposity. Nature 2012; 488:621-6.

27. Sudo N, Chida Y, Aiba Y, Sonoda J, Oyama N, Yu XN, et al. Postnatal microbial colonization programs the hypothalamic-pituitary-adrenal system for stress response in mice. J Physiol 2004; 558:263-75.

28. Yatsunenko T, Rey FE, Manary MJ, Trehan I, Dominguez-Bello MG, Contreras M, et al. Human gut microbiome viewed across age and geography. Nature 2012; 486:2227.

29. Fouhy F, Ross RP, Fitzgerald GF, Stanton C, Cotter PD. Composition of the early intestinal microbiota: knowledge, knowledge gaps and the use of high-throughput sequencing to address these gaps. Gut Microbes 2012; 3:203-20.

30. West CE. Gut microbiota and allergic disease: new findings. Curr Opin Clin Nutr Metab Care 2014; 17:261-6.

31. Dominguez-Bello MG, Costello EK, Contreras M, Magris M, Hidalgo G, Fierer N, et al. Delivery mode shapes the acquisition and structure of the initial microbiota across multiple body habitats in newborns. Proc Natl Acad Sci U S A 2010; 107:11971-5.

32. Gosalbes MJ, Llop S, Valles Y, Moya A, Ballester F, Francino MP. Meconium microbiota types dominated by lactic acid or enteric bacteria are differentially associated with maternal eczema and respiratory problems in infants. Clin Exp Allergy 2013; 43:198-211.

33. Rautava S, Luoto R, Salminen S, Isolauri E. Microbial contact during pregnancy, intestinal colonization and human disease. Nat Rev Gastroenterol Hepatol 2012; 9:565-76.

34. Aagaard K, Ma J, Antony KM, Ganu R, Petrosino J, Versalovic J. The placenta harbors a unique microbiome. Sci Transl Med 2014; 6:237ra65.

35. Azad MB, Konya T, Maughan H, Guttman DS, Field CJ, Chari RS, et al. Gut microbiota of healthy Canadian infants: profiles by mode of delivery and infant diet at 4 months. CMAJ 2013; 185:385-94.

36. Jakobsson HE, Abrahamsson TR, Jenmalm MC, Harris K, Quince C, Jernberg C, et al. Decreased gut microbiota diversity, delayed Bacteroidetes colonisation and reduced Th1 responses in infants delivered by caesarean section. Gut 2014; 63:559-66.

37. Penders J, Gerhold K, Stobberingh EE, Thijs C, Zimmermann K, Lau S, et al. Establishment of the intestinal microbiota and its role for atopic dermatitis in early childhood. J Allergy Clin Immunol 2013; 132:601-7 e8. 
38. Karlström A, Lindgren H, Hildingsson I. Maternal and infant outcome after caesarean section without recorded medical indication: findings from a Swedish case-control study. BJOG 2013; 120:479-86; discussion 86.

39. Kolokotroni O, Middleton N, Gavatha M, Lamnisos D, Priftis KN, Yiallouros PK. Asthma and atopy in children born by caesarean section: effect modification by family history of allergies - a population based cross-sectional study. BMC Pediatr 2012; 12:179.

40. Li H, Ye R, Pei L, Ren A, Zheng X, Liu J. Caesarean delivery, caesarean delivery on maternal request and childhood overweight: a Chinese birth cohort study of 181380 children. Pediatr Obes 2014;9:10-16.

41. Stene LC, Gale EA. The prenatal environment and type 1 diabetes. Diabetologia 2013; 56:1888-97.

42. Heintze K, Petersen KU. The case of drug causation of childhood asthma: antibiotics and paracetamol. Eur J Clin Pharmacol 2013; 69:1197-209.

43. Arumugam M, Raes J, Pelletier E, Le Paslier D, Yamada T, Mende DR, et al. Enterotypes of the human gut microbiome. Nature 2011; 473:174-80.

44. De Filippo C, Cavalieri D, Di Paola M, Ramazzotti M, Poullet JB, Massart S, et al. Impact of diet in shaping gut microbiota revealed by a comparative study in children from Europe and rural Africa. Proc Natl Acad Sci U S A 2010; 107:14691-6.

45. Jeffery IB, Claesson MJ, O'Toole PW, Shanahan F. Categorization of the gut microbiota: enterotypes or gradients? Nat Rev Microbiol 2012; 10:591-2.

46. Koren O, Knights D, Gonzalez A, Waldron L, Segata N, Knight R, et al. A guide to enterotypes across the human body: meta-analysis of microbial community structures in human microbiome datasets. PLoS Comput Biol 2013; 9:e1002863.

47. Bisgaard H, Li N, Bonnelykke K, Chawes BL, Skov T, Paludan-Muller G, et al. Reduced diversity of the intestinal microbiota during infancy is associated with increased risk of allergic disease at school age. J Allergy Clin Immunol 2011; 128:646-52 e1-5.

48. Abrahamsson TR, Jakobsson HE, Andersson Björkstén B, Engstrand L, Jenmalm MC. Low diversity of the gut microbiota in infants with atopic eczema. J Allergy Clin Immunol 2012; 129:434-40, 40 e1-2.

49. Ismail IH, Oppedisano F, Joseph SJ, Boyle RJ, Licciardi PV, Robins-Browne RM, et al. Reduced gut microbial diversity in early life is associated with later development of eczema but not atopy in high-risk infants. Pediatr Allergy Immunol 2012; 23:674-81.

50. van Nimwegen FA, Penders J, Stobberingh EE, Postma DS, Koppelman GH, Kerkhof $\mathrm{M}$, et al. Mode and place of delivery, gastrointestinal microbiota, and their influence on asthma and atopy. J Allergy Clin Immunol 2011; 128:948-55 e1-3.

51. Abrahamsson TR, Jakobsson HE, Andersson AF, Björkstén B, Engstrand L, Jenmalm MC. Low gut microbiota diversity in early infancy precedes asthma at school age. Clin Exp Allergy 2014; 44:842-50.

52. Nylund L, Satokari R, Nikkila J, Rajilic-Stojanovic M, Kalliomaki M, Isolauri E, et al. Microarray analysis reveals marked intestinal microbiota aberrancy in infants having eczema compared to healthy children in at-risk for atopic disease. BMC Microbiol $2013 ; 13: 12$.

53. Frank DN, St Amand AL, Feldman RA, Boedeker EC, Harpaz N, Pace NR. Molecular-phylogenetic characterization of microbial community imbalances in human inflammatory bowel diseases. Proc Natl Acad Sci U S A 2007; 104:13780-5.

54. Cheng J, Kalliomäki M, Heilig HG, Palva A, Lahteenoja H, de Vos WM, et al. Duodenal microbiota composition and mucosal homeostasis in pediatric celiac disease. BMC Gastroenterol 2013; 13:113. 
55. Merras-Salmio L, Kolho KL, Pelkonen AS, Kuitunen M, Makela MJ, Savilahti E. Markers of gut mucosal inflammation and cow's milk specific immunoglobulins in non-IgE cow's milk allergy. Clin Transl Allergy 2014; 4:8.

56. Vaarala O. Is the origin of type 1 diabetes in the gut? Immunol Cell Biol 2012; 90:271-6.

57. de Goffau MC, Luopajärvi K, Knip M, Ilonen J, Ruohtula T, Harkonen T, et al. Fecal microbiota composition differs between children with beta-cell autoimmunity and those without. Diabetes 2013; 62:1238-44.

58. Murri M, Leiva I, Gomez-Zumaquero JM, Tinahones FJ, Cardona F, Soriguer F, et al. Gut microbiota in children with type 1 diabetes differs from that in healthy children: a case-control study. BMC Med 2013; 11:46.

59. McDade TW. Early environments and the ecology of inflammation. Proc Natl Acad Sci U S A 2012; 109 Suppl 2:17281-8.

60. Yousuf O, Mohanty BD, Martin SS, Joshi PH, Blaha MJ, Nasir K, et al. Highsensitivity C-reactive protein and cardiovascular disease: a resolute belief or an elusive link? J Am Coll Cardiol 2013; 62:397-408.

61. Wang X, Bao W, Liu J, Ouyang YY, Wang D, Rong S, et al. Inflammatory markers and risk of type 2 diabetes: a systematic review and meta-analysis. Diabetes Care 2013; 36:166-75.

62. Jenny NS, Yanez ND, Psaty BM, Kuller LH, Hirsch CH, Tracy RP. Inflammation biomarkers and near-term death in older men. Am J Epidemiol 2007; 165:684-95.

63. Hanson M, Godfrey KM, Lillycrop KA, Burdge GC, Gluckman PD. Developmental plasticity and developmental origins of non-communicable disease: theoretical considerations and epigenetic mechanisms. Prog Biophys Mol Biol 2011; 106:272-80.

64. Huang RC, Mori TA, Burke V, Newnham J, Stanley FJ, Landau LI, et al. Synergy between adiposity, insulin resistance, metabolic risk factors, and inflammation in adolescents. Diabetes Care 2009; 32:695-701.

65. Cox LM, Yamanishi S, Sohn J, Alekseyenko AV, Leung JM, Cho I, et al. Altering the Intestinal Microbiota during a Critical Developmental Window Has Lasting Metabolic Consequences. Cell 2014; 158:705-21.

66. Karlsson CL, önnerfalt J, Xu J, Molin G, Ahrne S, Thorngren-Jerneck K. The microbiota of the gut in preschool children with normal and excessive body weight. Obesity (Silver Spring) 2012; 20:2257-61.

67. Kalliomäki M, Collado MC, Salminen S, Isolauri E. Early differences in fecal microbiota composition in children may predict overweight. Am J Clin Nutr 2008; 87:534-8.

68. Le Chatelier E, Nielsen T, Qin J, Prifti E, Hildebrand F, Falony G, et al. Richness of human gut microbiome correlates with metabolic markers. Nature 2013; 500:541-6.

69. FAO/WHO. Guidelines for the evaluation of probiotics in food. Report of a Joint FAO/WHO Working Group on Drafting Guidelines for the Evaluation of Probiotics in Food. World Health Organization, London Ontario, Canda. 2002.

70. Fiocchi A, Burks W, Bahna SL, Bielory L, Boyle RJ, Cocco R, et al. Clinical Use of Probiotics in Pediatric Allergy (CUPPA): A World Allergy Organization Position Paper. World Allergy Organ J 2012; 5:148-67.

71. Ege MJ, Bieli C, Frei R, van Strien RT, Riedler J, Ublagger E, et al. Prenatal farm exposure is related to the expression of receptors of the innate immunity and to atopic sensitization in school-age children. J Allergy Clin Immunol 2006; 117:817-23.

72. Bertelsen RJ, Brantsaeter AL, Magnus MC, Haugen M, Myhre R, Jacobsson B, et al. Probiotic milk consumption in pregnancy and infancy and subsequent childhood allergic diseases. J Allergy Clin Immunol 2014; 133:165-71 e1-8. 
73. Reiprich M, Rudzok S, Schutze N, Simon JC, Lehmann I, Trump S, et al. Inhibition of endotoxin-induced perinatal asthma protection by pollutants in an experimental mouse model. Allergy 2013; 68:481-9.

74. Kalliomäki M, Salminen S, Poussa T, Isolauri E. Probiotics during the first 7 years of life: a cumulative risk reduction of eczema in a randomized, placebo-controlled trial. J Allergy Clin Immunol 2007; 119:1019-21.

75. Jensen MP, Meldrum S, Taylor AL, Dunstan JA, Prescott SL. Early probiotic supplementation for allergy prevention: Long-term outcomes. J Allergy Clin Immunol 2012;130:1209-11.e5.

76. West CE, Hammarström ML, Hernell O. Probiotics in primary prevention of allergic disease - follow-up at 8-9 years of age. Allergy 2013; 68:1015-20.

77. Abrahamsson TR, Jakobsson T, Björkstén B, Oldaeus G, Jenmalm MC. No effect of probiotics on respiratory allergies: a seven-year follow-up of a randomized controlled trial in infancy. Pediatr Allergy Immunol 2013; 24:556-61.

78. Wickens K, Stanley TV, Mitchell EA, Barthow C, Fitzharris P, Purdie G, et al. Early supplementation with Lactobacillus rhamnosus HN001 reduces eczema prevalence to 6 years: does it also reduce atopic sensitization? Clin Exp Allergy 2013; 43:1048-57.

79. Loo EX, Llanora GV, Lu Q, Aw MM, Lee BW, Shek LP. Supplementation with probiotics in the first 6 months of life did not protect against eczema and allergy in atrisk Asian infants: a 5-year follow-up. Int Arch Allergy Immunol 2014; 163:25-8.

80. Azad MB, Coneys JG, Kozyrskyj AL, Field CJ, Ramsey CD, Becker AB, et al. Probiotic supplementation during pregnancy or infancy for the prevention of asthma and wheeze: systematic review and meta-analysis. BMJ 2013; 347:f6471.

81. Stefka AT, Feehley T, Tripathi P, Qiu J, McCoy K, Mazmanian SK, et al. Commensal bacteria protect against food allergen sensitization. Proc Natl Acad Sci U S A 2014; 111:13145-50.

82. Kuitunen M, Kukkonen K, Juntunen-Backman K, Korpela R, Poussa T, Tuure T, et al. Probiotics prevent IgE-associated allergy until age 5 years in cesarean-delivered children but not in the total cohort. J Allergy Clin Immunol 2009; 123:335-41.

83. Wang J, Tang H, Zhang C, Zhao Y, Derrien M, Rocher E, et al. Modulation of gut microbiota during probiotic-mediated attenuation of metabolic syndrome in high fat diet-fed mice. ISME J 2014, epub ahead of print.

84. Chorell E, Karlsson Videhult F, Hernell O, Antti H, West CE. Impact of probiotic feeding during weaning on the serum lipid profile and plasma metabolome in infants. Br J Nutr 2013; 110:116-26.

85. Kadooka Y, Sato M, Imaizumi K, Ogawa A, Ikuyama K, Akai Y, et al. Regulation of abdominal adiposity by probiotics (Lactobacillus gasseri SBT2055) in adults with obese tendencies in a randomized controlled trial. Eur J Clin Nutr 2010; 64:636-43.

86. Kumar M, Nagpal R, Kumar R, Hemalatha R, Verma V, Kumar A, et al. Cholesterollowering probiotics as potential biotherapeutics for metabolic diseases. Exp Diabetes Res 2012; 2012:902917.

87. Luoto R, Laitinen K, Nermes M, Isolauri E. Impact of maternal probioticsupplemented dietary counselling on pregnancy outcome and prenatal and postnatal growth: a double-blind, placebo-controlled study. Br J Nutr 2010; 103:1792-9.

88. Borre YE, O'Keeffe GW, Clarke G, Stanton C, Dinan TG, Cryan JF. Microbiota and neurodevelopmental windows: implications for brain disorders. Trends Mol Med 2014;20:509-18.

89. Ellwood P, Asher MI, Garcia-Marcos L, Williams H, Keil U, Robertson C, et al. Do fast foods cause asthma, rhinoconjunctivitis and eczema? Global findings from the International Study of Asthma and Allergies in Childhood (ISAAC) phase three. 
Thorax 2013; 68:351-60.

90. Thorburn AN, Macia L, Mackay CR. Diet, metabolites, and "western-lifestyle" inflammatory diseases. Immunity 2014; 40:833-42.

91. Osborn DA, Sinn JK. Prebiotics in infants for prevention of allergy. Cochrane Database Syst Rev 2013; 3:CD006474.

92. Vulevic J, Juric A, Tzortzis G, Gibson GR. A mixture of trans-galactooligosaccharides reduces markers of metabolic syndrome and modulates the fecal microbiota and immune function of overweight adults. J Nutr 2013; 143:324-31.

93. Korpela K, Flint HJ, Johnstone AM, Lappi J, Poutanen K, Dewulf E, et al. Gut microbiota signatures predict host and microbiota responses to dietary interventions in obese individuals. PLoS One 2014; 9:e90702.

94. Smits LP, Bouter KE, de Vos WM, Borody TJ, Nieuwdorp M. Therapeutic Potential of Fecal Microbiota Transplantation. Gastroenterology 2013;145:946-53.

95. Kassam Z, Lee CH, Yuan Y, Hunt RH. Fecal microbiota transplantation for Clostridium difficile infection: systematic review and meta-analysis. Am J Gastroenterol 2013; 108:500-8.

96. van Nood E, Vrieze A, Nieuwdorp M, Fuentes S, Zoetendal EG, de Vos WM, et al. Duodenal infusion of donor feces for recurrent Clostridium difficile. N Engl J Med 2013; 368:407-15.

97. Postigo R, Kim JH. Colonoscopic versus nasogastric fecal transplantation for the treatment of Clostridium difficile infection: a review and pooled analysis. Infection 2012; 40:643-8.

98. Hamilton MJ, Weingarden AR, Unno T, Khoruts A, Sadowsky MJ. High-throughput DNA sequence analysis reveals stable engraftment of gut microbiota following transplantation of previously frozen fecal bacteria. Gut Microbes 2013; 4:125-35.

99. Haahtela T, Holgate S, Pawankar R, Akdis CA, Benjaponpitak S, Caraballo L, et al. The biodiversity hypothesis and allergic disease: world allergy organization position statement. World Allergy Organ J 2013; 6:3. 